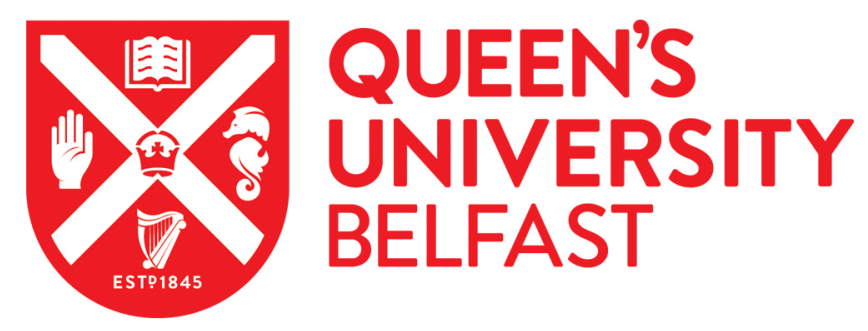

\title{
Determinants of Pesticide Application: An Empirical Analysis with Theory of Planned Behaviour
}

Wang, J., Chu, M., Yang, C., Lam, H., \& Tang, J. (2018). Determinants of Pesticide Application: An Empirical Analysis with Theory of Planned Behaviour. China Agricultural Economic Review, 10(4), 608-625. https://doi.org/10.1108/CAER-02-2017-0030

Published in:

China Agricultural Economic Review

Document Version:

Peer reviewed version

Queen's University Belfast - Research Portal:

Link to publication record in Queen's University Belfast Research Portal

Publisher rights

(c) 2018 Emerald Publishing Limited. This work is made available online in accordance with the publisher's policies. Please refer to any applicable terms of use of the publisher.

\section{General rights}

Copyright for the publications made accessible via the Queen's University Belfast Research Portal is retained by the author(s) and / or other copyright owners and it is a condition of accessing these publications that users recognise and abide by the legal requirements associated with these rights.

Take down policy

The Research Portal is Queen's institutional repository that provides access to Queen's research output. Every effort has been made to ensure that content in the Research Portal does not infringe any person's rights, or applicable UK laws. If you discover content in the Research Portal that you believe breaches copyright or violates any law, please contact openaccess@qub.ac.uk. 




\section{Determinants of Pesticide Application: An Empirical Analysis with Theory of Planned Behaviour}

\begin{tabular}{|r|l|}
\hline Journal: & China Agricultural Economic Review \\
\hline Manuscript ID & CAER-02-2017-0030.R4 \\
\hline Manuscript Type: & Research Paper \\
\hline Keywords: & $\begin{array}{l}\text { Structural equation modeling, pesticide application practices, Theory of } \\
\text { planned behaviour }\end{array}$ \\
\hline \multicolumn{2}{|l}{} \\
\hline
\end{tabular}

SCHOLARONE ${ }^{\prime \prime}$

Manuscripts 


\section{Determinants of Pesticide Application: An Empirical Analysis with Theory of Planned Behaviour}

3 Purpose -This paper aims to investigate farmers' intentions to comply with pesticide

4 application standards based on an extended Theory of Planned Behaviour (TPB).

5 Design/methodology/approach — Built on a $T P B$ framework, it was examined how perceived

6 behavioural control (PBC), behavioural goal, behavioural attitude, and subjective norm

7 influenced farmers' intention to comply with pesticide application standards. Data of 986

8 farmers from five major agricultural provinces in China were collected following a stratified

9 random sampling method. Structural equation modelling was employed for hypothesis testing 10 and analysis.

11 Findings - The results showed that $P B C$, behavioural goal, behavioural attitude, and

12 subjective norm had positive impacts on farmers' intention in abiding by the standards.

13 Among them in determining farmers' intention towards compliance with pesticide application

14 standards, farmers' $P B C$ was found to be the most influential factor, while subjective norm

15 was the least influential factor.

16 Originality/value - The results indicated that the traditional $T P B$ constructs had significant

17 correlations with farmers' intention to comply with pesticide standards, demonstrating the

18 applicability of the TPB in the understanding of farmers' decision-making in a developing

19 country context. It is suggested that psychological factors should be taken into consideration 20 in studying farmers' decision-making.

21 Keywords Theory of planned behaviour, structural equation modelling, pesticide application 22 practices

23 Paper type Research paper 


\section{1. Introduction}

2 The detrimental effects of pesticide residues present in agricultural products have aroused

3 concerns among the general public worldwide (De Krom and Mol, 2010; Wu and Hou, 2012).

4 Pesticide residues can be largely attributed to improper practices of pesticide application (Van

5 Asselt et al., 2010; Yang, 2003; Bourn and Prescott, 2002). It was suggested that application

6 of more pesticides than nessersary has caused the presence of pesticide residues in foods

7 (Ngowi et al., 2007). Currently, the application of pesticides is still essential to ensure

8 agricultural productivity growth. Hence, a thorough understanding of farmers' intention to use

9 pesticides in a safe manner is of interest to both policy makers and researchers.

10 Previous studies have generally focused on identifying the determinants of pesticide

11 overuse. It was argued that farmers' intention to guarantee harvests by over-spraying and the

12 absence of enforcement of pesticide regulations were two dominant factors contributing to

13 farmers' pesticide overuse (Stadlinger et al., 2011; Marcoux and Urpelainen, 2011).

14 Excessive use of pesticide was also ascribed to farmers' socio-economic status and farm

15 characteristics, e.g. education attainment, gender, and limited access to technical support

16 (Matthews, 2008; Jallow et al., 2017; Abhilash and Singh, 2009; Hruska and Corriols, 2002).

17 Other factors, such as farmers' perceptions towards pesticide risks, also influenced farmers'

18 pesticide overuse (Khan et al., 2015; Damalas and Hashemi, 2010; Liu and Huang, 2013).

19 Despite this extensive literature, a comprehensive theoretical framework is absent to 20 understanding farmers' pesticide application. Specifically, existing literature failed to address

21 the role psychological factors play in pesticide use (Escalada and Heong, 2012). As argued by

22 Hansson et al. (2012), there has been little understanding of the psychological roots

23 underlying farmers' decisions and behaviours. For instance, Grieshop et al. (1988) suggested

24 that farmers' decisions on pest control were subjective and depended on psychological factors

25 such as personal beliefs and perceptions. Put it differently, economic models alone cannot

26 capture the complexity of farmers' motivation and behaviour (Lynne and Rola, 1988;

27 Vanslembrouck et al., 2002; Gartrell and Gartrell, 1985). To provide a comprehensive picture

28 of farmers' intention and behaviour, a psychological model is necessary.

29 The objective of this paper is to use the Theory of Planned Behaviour (TPB) to analyse

30 the determinants affecting farmers' intentions to comply with standards of pesticide usage, 
1 which offers a theoretical foundation to study how psychological factors influence human

2 behaviours. We aim to provide constructive policy recommendations to facilitate

3 governments' amendments on pesticide application policies. The remainder of this study is

4 organized as follows. Section 2 explains the theoretical framework and the associated

5 hypotheses. Section 3 describes the survey design and measurement of variables. The

6 methodology and results are presented in section 4. Finally, discussions, policy implications

7 and limitations of this research are given in section 5.

\section{2. Theoretical framework and hypotheses}

9 2.1. Theoretical framework

10 The TPB (Ajzen, 1985; 1991) was developed upon the theory of reasoned action (Fishbein

11 and Ajzen, 1975; Ajzen and Fishbein, 1980). The TPB states that intention is a necessary

12 condition for planned behaviour (Ajzen and Madden, 1986), while behavioural intention is

13 influenced by three psychological constructs, namely attitude, subjective norm and perceived

14 behavioural control. Attitude refers to the degree to which a person appraises the behaviour in question (Beedell and Rehman, 2000; Wauters et al., 2010). Subjective norm is defined as the perceived social pressure to perform a pro-social behaviour, whereas perceived behavioural control refers to an individual's perception of his/her ability to perform that behaviour (Fishbein and Ajzen, 1975). According to $T P B$, the more an individual is favourable of his/her attitudes, subjective norm and perceived behavioural control, the stronger intention he/she has to perform a particular behaviour (Ajzen, 1991; Davis et al., 2002).

Recent studies have attempted to improve the predictive power of TPB by adding extra variables, such as past behaviours and habits (Chow and Mullan, 2010; McGilligan et al., 2009; Smith et al., 2007). Mazzocchi et al. (2006) integrated risk perception and trust into the TPB framework to analyse consumers' chicken purchasing behaviour after the outbreak of avian influenza. Bai et al. (2014) fitted the TPB into the Chinese context by replacing the subjective norm with 'face consciousness' and 'conformity consciousness'.

As an emerging area, $T P B$ has been used in the context of agriculture to understand farmers' strategic and entrepreneurship (Bergevoet et al., 2004), conservation-related behaviour (Beedell and Rehman, 2000), adoption and investment of water-saving 
1 technologies (Lynne et al., 1995), as well as the intention to adopt organic farming activities 2 (Läpple and Kelley, 2013).

Borges and Lansink (2016) suggested that farmers' intention to use improved natural grassland was mainly determined by subjective norm, followed by perceived behavioural 5 control, and the attitude towards improved natural grassland. In an analysis of Belgian

6 farmers' intention to adopt soil erosion control techniques, Wauters et al. (2010) found that

7 the most influential factor was farmers' attitude towards such practices. This study applies an

8 extended $T P B$ to explore farmers' intention to comply with pesticide standards. Structural Equation Modeling (SEM) was used because farmers' intention and its psychological determinants are latent variables, i.e. the variables which exist but cannot be directly observed. SEM allows the measurement of latent variables and modelling of the relationships among the latent variables (Kline, 2015).

In this study, behavioural goal is taken as an additional construct to the TPB. Human beings are goal-oriented, self-motivated, and have the ability to think ahead (Binswanger, 1980; Locke and Bryan, 1969). Once a goal is set, it is printed in an individual's fringe of consciousness as a reference point that guides his or her mental and physical behaviours (Locke and Latham, 2006). Goals also help one to set priorities and to acquire information (Willock et al., 1999). Consequently, farmers aim to maximise profits, and to pursue other values such as security, honour, and social status (Han, 1995). Willock et al. (1999) identified five goals among Scottish farmers, i.e. success in farming, sustainability, high quality of life, high social status, and more off-farm activities. However, farmers' behavioural goals might differ across their economic status and the availability of resources (Kong, 1998). When basic survival needs are met, farmer's main goal will switch to increasing household income; when household income reaches a certain level, farmers will then pursuit higher quality of life or more leisure time (Gao et al., 2013).

Due to the fact that Chinese farmers generally have low income, we assume that profit maximisation is a dominant production goal. As a result, economic goals are our key concern when it comes to farmers' behaviour goals. Specifically, they are expected to comply with pesticide usage regulation in order to: (1) lower production costs by reducing pesticide use; (2) increase revenues by rising yield; or (3) increase crop prices by producing safer and better 
1 quality foods. Note that goals are rather general or even abstract, whereas objectives are more

2 specific and are in terms of profitability and productivity (Zimmerer et al., 2005). In this

3 study we refer to goals rather than objectives.

The $T P B$ is an ideal framework to study farmers' pesticide usage for the following

5 reasons. First, farmers' pesticide usage requires careful planning, which is a characteristic

6 favourable to the application of the TPB (Krueger et al., 2000). Second, farmers' behaviours

7 are not solely influenced by profit maximisation (Gasson, 1973). Finally, the TPB is easy to

8 implement and is applicable to a wide range of behavioural domains (Leone et al., 1999).

9 Consequently, the $T P B$ is adopted to understand whether farmers' intention to comply with pesticide usage standards is shaped by beliefs, social pressures, perceived behavioural control,

11 and behavioural goal. This study contributes to the understanding of pesticide usage

12 behaviour by highlighting the role of psychological factors which should be taken into

13 consideration in the study of farmers' intention and decisions.

14

\subsection{Hypotheses}

\section{Perceived behavioural control}

Perceived behavioural control $(P B C)$ refers to a farmer's perception of his/her ability to comply with standards for pesticide application. $P B C$ is largely constrained by the limited resources owned by farmers, e.g. land, capital, knowledge, ability, and technology (Zhou, 2006). Lin (1988) stated that farmers' decisions were restricted by their limited competence and tough economic conditions. Lacking time and expenses was reported as the main reasons for the limited adoption of protective equipment (Damalas et al., 2006). Furthermore, pesticide retailers and authorities may play important roles in providing information and guidance to facilitate farmers' pesticide selection and to increase their awareness of pesticide risks. In general, the greater the $P B C$, the more confident a farmer is to carry out a specific action. In the case of pesticide usage, farmers make evaluations of the consequences of pesticide overuse based on the exposure to technical guidance and their own and neighbours' experience. If a farmer has a better understanding of pesticides, he/she would be more likely to avoid improper pesticide usage. In contrast, if a farmer perceives himself/herself as lacking resources such as time, money and knowledge, he/she would have less intention to carry out 
1 the action. Du et al. (2014) found that safety regulations and information services provided by

2 the government and pesticide retailers also enhanced farmers' $P B C$. Moreover, $P B C$ was

3 statistically related to sustainable agricultural activities (Fielding et al., 2008). Therefore, it is

4 hypothesised that:

$5 \quad H 1$. $P B C$ has a positive influence on farmers' intention to comply with standards of

6 pesticide application.

\section{Behavioural goal}

8 Behavioural goal is defined as the goal farmers are expecting when complying with 9 pesticide usage standards. Behavioural economists emphasized the roles of goals, attitudes, 10 and other psychological factors in influencing farmers' decisions (Wilson, 1996). Most

11 successful enterprises had entrepreneurial goals, e.g. an impressive brand image, large market 12 shares, and a recognisable social image of enterprises. For instance, a food company which

13 aims to lead the market will take initiatives to implement a variety of production criteria and 14 regulations to guarantee the safety and quality of its products. Similarly, the farmers who 15 pursue specific farming goals will adopt necessary agricultural practices. Bergevoet et al. 16 (2004) concluded that Dutch dairy farmers were driven by both revenue and non-revenue 17 goals which had notable impacts on their decision making. For instance, the goal to own a 'large and modern farm' was positively associated with farm size (i.e. the milk quota of a

19 farm). Other studies also demonstrated that farmers' behavioural goal had positive impacts on 20 their behavioural intention and actual behaviours (Jiang et al., 2012; Zhao and Zhang, 2009).

21 Therefore, it is hypothesised that:

22 H2. Behavioural goal has a positive influence on farmers' intention to comply with 23 standards of pesticide application.

\section{Behavioural attitude}

Behavioural attitude refers to both positive and negative attitudes that farmers display towards the compliance with pesticide application standards. It includes both cognitive and emotional evaluations (McGuire, 1969). Furthermore, it was studied extensively that attitudes had significance influences on behavioural intentions (Ajzen and Fishbein, 1980). In an application of TPB, Karppinen (2005) found that farmers' attitudes explained farmers' 
1 choices to produce safe foods. Pampel and van Es (1977) pointed out that the attitude towards

2 profit maximization and sustainability determined the type of technological innovation

3 adopted. Lynne and Rola (1988) have reported similar results. Zhou (2006) found that farmers

4 who had favourable attitudes towards the quality and safety of vegetables were more likely to

5 adopt quality control practices. Therefore, it is hypothesised that:

6

7 standards of pesticide application.

\section{$8 \quad$ Subjective norm}

9 Subjective norm refers to the social pressures perceived by farmers during pesticide usage.

10 Farmers are expected to reconsider the consequences of improper pesticide usage in the

11 presence of social norm that encourages better practices. Hence, they tend to perform

12 pro-social behaviours under the pressure of peers. In the case of pesticide usage, farmers'

13 actions are expected to be influenced by their relatives, friends, neighbours and government

14 agencies. We consider both normative and informational influences from referents. The

15 former relates to an individual's conformity with expectations of other individuals

16 surrounding him/her (Homans, 1961). Farmers may be unwilling to comply with standards of

17 pesticide usage in the beginning, but they may change their behaviours as a response to the

18 social pressures from the people surrounding them. The latter refers to the credible

19 information provided by informants (Burnkrant and Cousineau, 1975). It is crucial for farmers

20 to make informed decisions. Farmers' perception of safe pesticide usage is expected to

21 originate from the credible information provided by authorities. Therefore, it is hypothesised 22 that:

\section{Interaction effects}

26 Interaction effects refer to the phenomenon that the influence of a latent psychological

27 factor on intention might depend on other psychological factors. It is suggested that

28 interaction effects between $P B C$ and attitude are evident so that a positive attitude motivates 29 an individual to perform certain behaviours, as he/she perceives a high degree of 
1 controllability over the behaviour (Ajzen, 1985; Ajzen and Driver, 1992; Eaglyand Chaiken,

2 1993). Other studies have also suggested that attitude might interact with subjective norms

3 (Acock and Defleur, 1972; Grube et al., 1986). For instance, a farmer may develop a

4 positive attitude when he/she feels that significant others expect him/her to comply with

5 pesticide usage standards. The mutual interactions between the other latent psychological

6 factors might also exist and are subject to empirical tests.

H5. Interaction effects among latent variables exist.

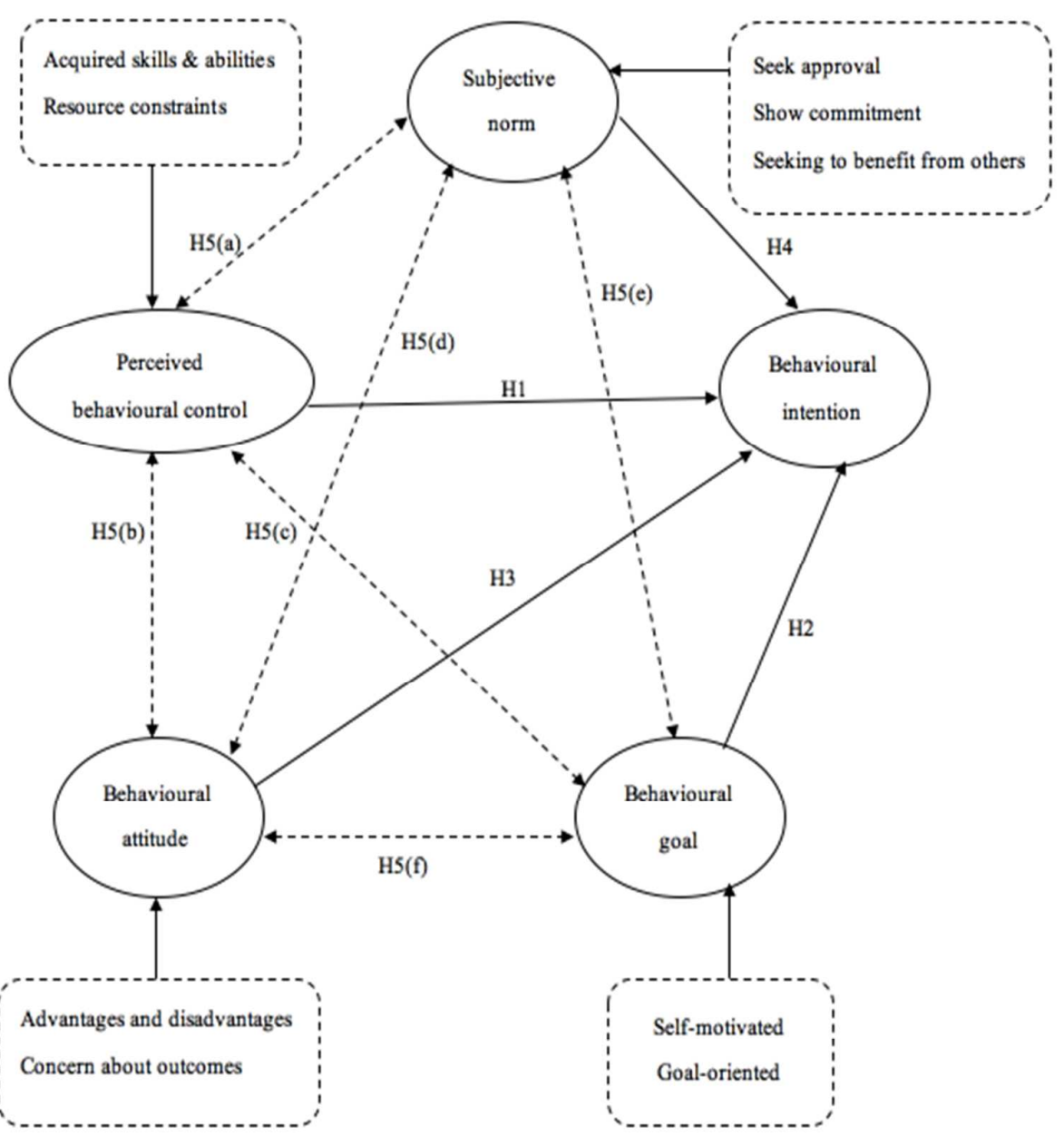

10 Figure 1: A theoretical model incorporating psychological factors that influence farmers' intentions to 11 comply with pesticide use standards

12 Note: A solid line represents a dependence relationship and a dotted line represents a correlation 13 relationship.

\section{3. Method}




\section{3.1. Data collection and sample}

2 Prior to the full survey, a preliminary questionnaire had been pre-tested by ten farmers and

3 two specialists. The final questionnaire was composed of five sections, i.e. socio-economic

4 characteristics, traditional TPB psychological factors, farmers' behavioural goals, risk

5 perception, and personal traits. Face-to-face interviews were carried out with household heads

6 to collect detailed information on their pesticide usage. A stratified random sampling

7 approach was followed. Samples were selected from five major agricultural Chinese

8 provinces where large amounts of pesticides were consumed, i.e. Henan, Shandong, Jiangsu,

9 Zhejiang, and Heilongjiang. Four counties were randomly selected from each of the five

10 provinces, leading to 20 counties. Next, five villages were randomly selected from each

11 county. Finally, ten farmers from each of village were interviewed individually by an

12 interviewer. The survey team was guided by local villagers with sound personal networks to

13 ensure that the survey could be carried out smoothly. To ensure the credibility of farmers'

14 responses, the survey team clearly explained to farmers their identity as university researchers

15 prior to the interviewing. Additionally, unanswered questions were further explained and

16 filled in by farmers to ensure a high response rate. While farmers might have under-reported

17 their pesticide usage, we endeavoured to minimise the downward bias in two ways. First,

18 interviewers received extensive training prior to the interviews. A guided dialogue was

19 designed for the interviewers to avoid deliveries of any normative messages. Second,

20 interviewers were asked to clearly explain their identity as researchers to ensure that farmers

21 understood that the survey was anonymous and that their privacy will be protected.

22 In total, 1,000 questionnaires were distributed between February and March 2013,

23 among which 993 questionnaires were returned. Seven invalid questionnaires were excluded, 24 resulting in 986 valid responses. Table 1 summarises the details of the sampling strategy.

25 Table 1: Distribution of samples

\begin{tabular}{cccc}
\hline Province & No. of counties & No. of villages & No. of samples \\
\hline Shandong & 4 & 5 & 183 \\
Henan & 4 & 5 & 196 \\
Jiangsu & 4 & 5 & 200 \\
Zhejiang & 4 & 5 & 199 \\
Heilongjiang & 4 & 5 & 208 \\
\hline
\end{tabular}




\section{$1 \quad 3.2$. Measurements of constructs}

2 Following Fishbein and Ajzen (2010), 19 observed variables were used to measure the five

3 psychological constructs. In line with previous $T P B$ studies, all variables were measured using

4 the five-point Likert scale (Läpple and Kelley, 2013; Bergevoet et al., 2004). The final

5 questionnaire items used to measure each construct are listed in Table 2.

6 Table 2: Questions used to measure the psychological constructs

\begin{tabular}{|c|c|c|c|c|}
\hline Notations & Questions & Scales $(1-5)$ & Mean & S.D. \\
\hline$B I 1$ & $\begin{array}{l}\text { How likely is it that you will pay attention to } \\
\text { pesticide residues in order to avoid food safety } \\
\text { risks? }\end{array}$ & $\begin{array}{l}\text { "Very unlikely" - } \\
\text { "Very likely" }\end{array}$ & 3.53 & 0.789 \\
\hline$B I 2$ & $\begin{array}{l}\text { How likely is it that you will read the label } \\
\text { carefully before spraying pesticides? }\end{array}$ & $\begin{array}{l}\text { "Very unlikely" - } \\
\text { "Very likely" }\end{array}$ & 4.20 & 0.822 \\
\hline$B I 3$ & $\begin{array}{l}\text { How likely is it that you will lower your } \\
\text { pesticide usage in the next year? }\end{array}$ & $\begin{array}{l}\text { "Very unlikely" - } \\
\text { "Very likely" }\end{array}$ & 3.55 & 0.925 \\
\hline$B A 1$ & $\begin{array}{l}\text { To what extent are you concerned about the } \\
\text { danger to agricultural products when there is } \\
\text { pesticide residue left on them? }\end{array}$ & $\begin{array}{l}\text { "Not at all" - "Very } \\
\text { much" }\end{array}$ & 3.42 & 0.929 \\
\hline$B A 2$ & $\begin{array}{l}\text { To what extent do you agree that safe } \\
\text { agricultural products would taste better? }\end{array}$ & trongly agree & 3.73 & 0.660 \\
\hline$B A 3$ & $\begin{array}{l}\text { To what extent do you agree that compliance } \\
\text { with pesticide application standards would be } \\
\text { beneficial to you? }\end{array}$ & $\begin{array}{l}\text { "Strongly disagree" } \\
\text { - "Strongly agree }\end{array}$ & 3.69 & 0.735 \\
\hline BA4 & $\begin{array}{l}\text { To what extent do you agree that it's wise to } \\
\text { comply with pesticide application standards? }\end{array}$ & $\begin{array}{l}\text { "Strongly disagree" } \\
\text { - "Strongly agree }\end{array}$ & 3.80 & 0.839 \\
\hline$B A 5$ & $\begin{array}{l}\text { To what extent do you agree that it would be } \\
\text { reasonable to grow pollution-free, green and } \\
\text { organic agricultural products? }\end{array}$ & $\begin{array}{l}\text { "Strongly disagree" } \\
\text { - "Strongly agree }\end{array}$ & 3.81 & 0.814 \\
\hline SN1 & $\begin{array}{l}\text { To what extent are you influenced by your } \\
\text { family members to comply with pesticide usage } \\
\text { standards? }\end{array}$ & $\begin{array}{l}\text { "Not at all" - "Very } \\
\text { much" }\end{array}$ & 3.25 & 1.012 \\
\hline SN2 & $\begin{array}{l}\text { To what extent are you influenced by your } \\
\text { friends to comply with pesticide usage } \\
\text { standard? }\end{array}$ & $\begin{array}{l}\text { "Not at all" - "Very } \\
\text { much" }\end{array}$ & 2.90 & 1.002 \\
\hline SN3 & To what extent are you influenced by other & "Not at all" - "Very & 3.09 & 0.928 \\
\hline
\end{tabular}




\begin{tabular}{|c|c|c|c|c|}
\hline & $\begin{array}{l}\text { farmers to comply with pesticide usage } \\
\text { standards? }\end{array}$ & much" & & \\
\hline SN4 & $\begin{array}{l}\text { To what extent are you influenced by the } \\
\text { government to comply with pesticide usage }\end{array}$ & $\begin{array}{l}\text { "Not at all" - "Very } \\
\text { much" }\end{array}$ & 3.26 & 1.110 \\
\hline PBC1 & $\begin{array}{l}\text { You have the knowledge and skills to regulate } \\
\text { pesticide application on your farm. }\end{array}$ & $\begin{array}{l}\text { "Strongly disagree" } \\
\text { - "Strongly agree }\end{array}$ & 2.91 & 1.064 \\
\hline$P B C 2$ & $\begin{array}{l}\text { To what extent does the government supervise } \\
\text { your pesticide application practices? }\end{array}$ & $\begin{array}{l}\text { "Very little" - "Very } \\
\text { much" }\end{array}$ & 3.62 & 1.154 \\
\hline$P B C 3$ & $\begin{array}{l}\text { To what extent do you agree that having } \\
\text { technical guidance on pesticide spray on your } \\
\text { farm has a strong regulatory impact on your } \\
\text { behaviour? }\end{array}$ & $\begin{array}{l}\text { "Strongly disagree" } \\
\text { - "Strongly agree }\end{array}$ & 3.39 & 1.177 \\
\hline$P B C 4$ & $\begin{array}{l}\text { It's totally up to me whether I regulate my } \\
\text { pesticide application. }\end{array}$ & $\begin{array}{l}\text { "Strongly disagree" } \\
\text { - "Strongly agree }\end{array}$ & 3.65 & 1.132 \\
\hline$B G$ & To what extent do you agree that you produc & agricultural products & order to & \\
\hline$B G 1$ & ...lower the production cost? & $\begin{array}{l}\text { "Strongly disagree" } \\
\text { _ "Strongly agree }\end{array}$ & 3.82 & 0.697 \\
\hline$B G 2$ & ...increase the total revenue? & Strongly disagree' & 3.60 & 0.742 \\
\hline$B G 3$ & ...increase the product price? & $\begin{array}{l}\text { "Strongly disagree" } \\
\text { - "Strongly agree }\end{array}$ & 3.82 & 0.709 \\
\hline
\end{tabular}

1 3.3. Description of the sample

2 Table 3 shows the social-demographic characteristics of the 986 respondents. Overall, $3 \quad 85.7 \%$ of the respondents were younger than 60 years old with nearly half (41.6\%) between 446 and 60 years. More than half (59.8\%) of the respondents were males, reflecting the fact 5 that pesticide spray was generally done by males. A majority of respondents (94.2\%) were 6 married and a large proportion of the respondents (78.9\%) only had junior high-school or 7 lower education.

8 Table 3: Sample characteristics $(N=986)$

\begin{tabular}{llccc}
\hline Characteristics & Item response and score & \% sample & Mean & S.D. \\
\hline Gender & "Male" $=1$ & 59.84 & 1.40 & 0.490 \\
\hline
\end{tabular}




\begin{tabular}{|c|c|c|c|c|}
\hline & "Female" = 2 & 40.16 & & \\
\hline & $"<18$ years old" $=1$ & 0.91 & & \\
\hline & "18-25 years old" $=2$ & 7.61 & & \\
\hline Age & $" 26-45$ years old" $=3$ & 35.60 & 3.61 & 0.855 \\
\hline & $" 46-60$ years old" $=4$ & 41.58 & & \\
\hline & $" \geq 61$ years old" $=5$ & 14.30 & & \\
\hline \multirow{5}{*}{ Educational level } & "Primary school and below" $=1$ & 29.92 & \multirow{5}{*}{2.00} & \multirow{5}{*}{0.908} \\
\hline & "Junior high school" = 2 & 48.99 & & \\
\hline & "Senior high school" $=3$ & 15.52 & & \\
\hline & "Junior college" $=4$ & 2.64 & & \\
\hline & "College and above" $=5$ & 2.93 & & \\
\hline
\end{tabular}

1

\section{4. Validation of measurements}

3 4.1. Exploratory factor analysis

4

5

6 7

In the first stage, SPSS (version 18) was employed to conduct an exploratory factor analysis, which is a useful tool to validate measurements for latent variables (Beran and Violato, 2010). It is a common practice to use exploratory factor analysis in the first stage to explore the possible indicators for latent variables and then use the validated indicators in subsequent SEM analysis. A similar practice was followed in several TPB studies as well (see among others Bai et al., 2014; Verbeke and Vackier, 2005). Additionally, exploratory factor analysis allows the tests of data suitability by conducting sampling adequacy tests, namely Kaiser-Meyer-Olkin $(K M O)$ test and Bartlett's sphericity test. $K M O$ returned a value of 0.821 and the approximate Chi-square from Bartlett's sphericity test was highly significant ( $p<0.001$ ), suggesting that the data collected were suitable for factor analysis and that the null

4 hypothesis was rejected. Oblique rotation method was applied to determine the number of 5 items allocated to each factor (Fabrigar et al., 1999). The rotated factor loading matrix is 6 illustrated in Table 4. Finally, five factors were identified and 19 items were obtained. 
1 Test validity has two components, namely content validity and construct validity. Content

2 validity refers to the representativeness and appropriateness of the measurement methods, i.e.

3 whether indicators reflect the characteristics of the latent variables (Wang and Wang, 2012).

4 During the conceptualisation of the questionnaire, we considered how previous studies

5 measured the five latent variables to ensure content validity (Bai et al., 2014; Fielding et al.,

6 2008). Construct validity refers to the degree to which the indicators can measure the

7 constructs. A factor analysis was conducted to evaluate construct validity. The results showed

8 that factor loadings were all greater than 0.5 , indicating that the constructs had satisfactory

9 construct validities.

10 The reliability of a psychological construct shows whether its measurement is consistent 11 and stable (Wang and Wang, 2012). This study tested the reliability of the five exploratory

12 factors by observing the Cronbach's $\alpha$ coefficient. A Cronbach's $\alpha$ coefficient higher than 0.6

13 indicates that the measurements can be used to represent the constructs (Borges et al., 2014;

14 Bruijnis et al., 2013). The results of reliability and construct validity tests are summarised in

15 Table 4. The Cronbach's $\alpha$ of all five factors ranged from 0.646 to 0.858 , indicating a

16 relatively high internal consistency.

17 Table 4: Reliability and construct validity tests

\begin{tabular}{|c|c|c|c|c|c|}
\hline \multirow{2}{*}{$\begin{array}{l}\text { Latent } \\
\text { constructs }\end{array}$} & \multirow{2}{*}{ Items } & Reliability & \multicolumn{3}{|c|}{ Construct validity } \\
\hline & & Cronbach $\alpha$ & Factor loadings & Guttman Split-half & Variance contribution rate \\
\hline \multirow{3}{*}{$\begin{array}{l}\text { Behavioural } \\
\text { intention }(B I)\end{array}$} & $B I 1$ & & 0.615 & & \\
\hline & $B I 2$ & 0.646 & 0.544 & 0.646 & \\
\hline & $B I 3$ & & 0.673 & & \\
\hline \multirow{4}{*}{$\begin{array}{l}\text { Behavioural } \\
\text { attitude }(B A)\end{array}$} & $B A 1$ & & 0.658 & & \\
\hline & $B A 2$ & & 0.597 & & \\
\hline & $B A 3$ & 0.781 & 0.689 & 0.743 & 54.188 \\
\hline & $B A 4$ & & 0.745 & & \\
\hline \multirow{4}{*}{$\begin{array}{l}\text { Subjective } \\
\text { norm }(S N)\end{array}$} & $B A 5$ & & 0.808 & & \\
\hline & $S N 1$ & & 0.847 & & \\
\hline & $S N 2$ & 0.750 & 0.810 & 0.689 & 58.247 \\
\hline & SN3 & & 0.770 & & \\
\hline
\end{tabular}




$\begin{array}{lccccc} & S N 4 & & 0.599 & & \\ \text { Perceived } & P B C 1 & & 0.736 & & 70.231 \\ \text { behavioural } & P B C 2 & 0.858 & 0.851 & 0.849 & \\ \text { control }(P B C) & P B C 3 & & 0.866 & & \\ & P B C 4 & 0.820 & & 61.748 \\ \text { Behavioural } & B G 1 & & 0.722 & & \\ \text { goal }(B G) & B G 2 & 0.688 & 0.752 & 0.675 & \\ & B G 3 & & 0.794 & & \end{array}$

1 4.3. The measurement model

2 In the next stage, a confirmatory factor analysis was carried out using the maximum

3 likelihood procedure in SEM. In this study, seven conventional model-fit statistics are chosen,

4 namely Chi-square/degrees-of-freedom $\left(\chi^{2} / d f\right)$, goodness-of-fit $(G F I)$, adjusted

5 goodness-of-fit $(A G F I)$, standardised root mean square error of approximation (RMSEA),

6 comparative fit index $(C F I)$, incremental fit index (IFI), and normed fit index $(N F I)$.

7 Generally, values greater than 0.9 for GFI, AGFI, CFI, IFI, NFI indicate acceptable model fits

8 (Bagozzi et al., 1991). Moreover, a RMSEA value less than 0.05 is necessary (Browne and

9 Cudeck, 1993). The recommended minimum cut-off values and the observed values in our

10 study are presented in Table 5. The overall model-fit statistics is $\chi^{2} / d f=1.701$, which is

11 less than the cut-off value (3.0) suggested by Carmines and Mciver (1981). The other

12 model-fit statistics also demonstrated reasonably good model-fit.

13 Table 5: Goodness-of-fit test statistics

\begin{tabular}{llllllll}
\hline Fit index & $\chi^{2} / d f$ & GFI & CFI & RMSEA & AGFI & IFI & NFI \\
\hline Suggested value & $<3$ & $>0.9$ & $>0.9$ & $<0.05$ & $>0.9$ & $>0.9$ & $>0.9$ \\
Observed value & 1.701 & 0.966 & 0.966 & 0.042 & 0.948 & 0.967 & 0.948 \\
Conclusion & Accepted & Good fit & Good fit & Good fit & Good fit & Good fit & Good fit \\
\hline
\end{tabular}

14 


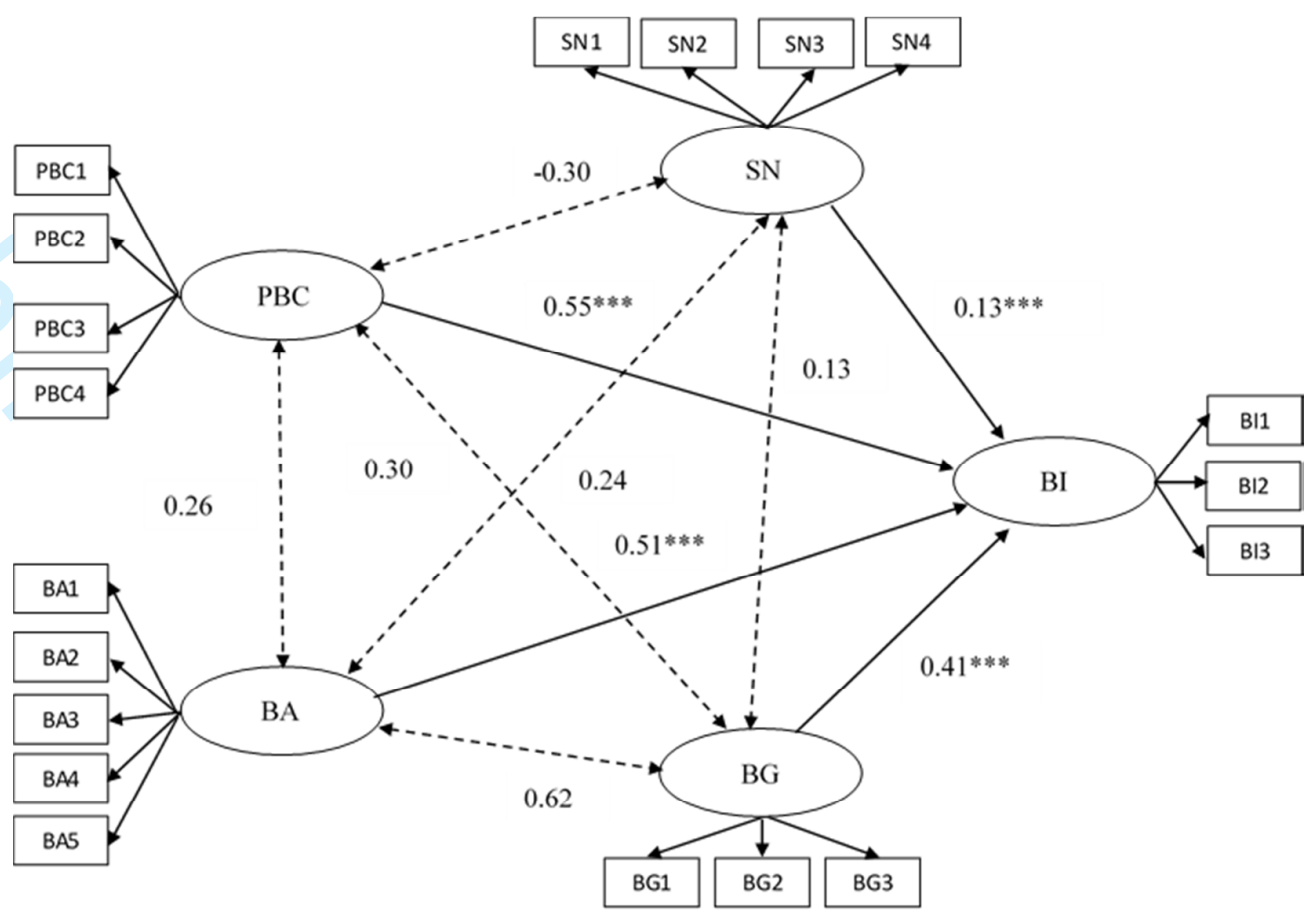

1

2 Figure 2. Path diagram of SEM.

3 Note: $* * * \mathrm{p}<0.01$.

\section{4.4. Path analysis of the structural model}

5 Path analysis represents the causal relationships and correlations among latent variables. It

6 can be used to assess the significance of a path (Wright, 1920). Table 6 shows the results of

7 SEM estimated using $A M O S$, based on the sample of 986 farmers. The standardised path

8 coefficients of $P B C, B G, B A$, and $S N$ are $0.55(\mathrm{p}<0.01), 0.41(\mathrm{p}<0.01), 0.51(\mathrm{p}<0.01)$ and 0.13

$9 \quad(\mathrm{p}<0.10)$, respectively, indicating that $P B C$ has the largest influence on farmers' intention to comply with pesticide usage standards, whereas $S N$ has the lowest influence.

The positive and significant correlation between $B I$ and $P B C(0.55, \mathrm{p}<0.01)$ indicates that farmers' perceptions about their compliance capabilities was an important factor to promote their $B I$. The results implied that farmers' intention to comply pesticide application standards was closely related to the supervision and technical support provided by the government.

The results also accord hypothesis $H 2$ because a positive and significant correlation between $B G$ and $B I(0.41, \mathrm{p}<0.01)$ was reported. That means that farmers complied with pesticide application standards to achieve their goals, i.e. reducing production costs, raising yield, and increasing market prices of their products. 
1 Hypothesis $H 3$ is supported because $B A$ had a positive and significant correlation with $B I$

$2(0.51, p<0.01)$. This indicates that farmers were more likely to comply when they paid more

3 attention to food safety issues and were more aware of the importance of safe agricultural

4 products.

5 Lastly, the standardised path coefficient of $S N$ was 0.13 , confirming hypothesis $H 4$. The

6 rationale is that a farmer's intention was highly influenced by the farmer's relatives, friends,

7 and neighbours. This is parallel to the theory that social pressures motivate farmers to use

8 pesticide properly (Borges et al., 2014).

9 Table 6: SEM path coefficients

\begin{tabular}{|c|c|c|c|c|c|}
\hline Paths & Coefficients & S.E. & $\begin{array}{l}\text { Critical } \\
\text { ratios }\end{array}$ & $\begin{array}{c}\text { Standardised } \\
\text { path coefficients }\end{array}$ & $\begin{array}{c}\text { Significance } \\
\text { levels }\end{array}$ \\
\hline \multicolumn{6}{|l|}{ Structural model } \\
\hline$B I<---P B C$ & 0.547 & 0.030 & 7.772 & 0.55 & $* * *$ \\
\hline$B I<---B G$ & 0.209 & 0.065 & 4.129 & 0.41 & $* * *$ \\
\hline$B I<---B A$ & 0.512 & 0.066 & 4.973 & 0.51 & $* * *$ \\
\hline$B I<---S N$ & 0.128 & 0.042 & 1.897 & 0.13 & 0.058 \\
\hline \multicolumn{6}{|l|}{ Interactions } \\
\hline$P B C<-->B G$ & 0.144 & 0.019 & 7.464 & 0.30 & $* * *$ \\
\hline$B G<-->B A$ & 0.194 & 0.017 & 11.509 & 0.62 & $* * *$ \\
\hline$P B C<-->B A$ & 0.128 & 0.020 & 6.367 & 0.26 & $* * *$ \\
\hline$B A<-->S N$ & 0.079 & 0.014 & 5.682 & 0.24 & $* * *$ \\
\hline$B G<-->S N$ & 0.042 & 0.013 & 3.163 & 0.13 & $* * *$ \\
\hline$P B C<-->S N$ & -0.015 & 0.018 & -0.850 & -0.30 & 0.395 \\
\hline \multicolumn{6}{|l|}{ Measurement models } \\
\hline$P B C 1<---P B C$ & 0.621 & 0.037 & 20.211 & 0.62 & $* * *$ \\
\hline$P B C 2<---P B C$ & 0.812 & 0.040 & 27.272 & 0.81 & $* * *$ \\
\hline$P B C 3<---P B C$ & 0.904 & 0.042 & 29.146 & 0.90 & $* * *$ \\
\hline$P B C 4<---P B C$ & 0.768 & - & - & 0.77 & \\
\hline$B G 1<---B G$ & 0.534 & 0.048 & 14.074 & 0.53 & $* * *$ \\
\hline$B G 2<---B G$ & 0.655 & 0.053 & 16.551 & 0.66 & $* * *$ \\
\hline$B G 3<---B G$ & 0.777 & - & - & 0.78 & \\
\hline$B A 1<---B A$ & 0.506 & 0.061 & 13.372 & 0.51 & $* * *$ \\
\hline$B A 2<---B A$ & 0.648 & 0.049 & 15.265 & 0.65 & $* * *$ \\
\hline$B A 3<---B A$ & 0.730 & 0.055 & 17.133 & 0.73 & $* * *$ \\
\hline$B A 4<---B A$ & 0.643 & 0.049 & 19.221 & 0.64 & $* * *$ \\
\hline$B A 5<---B A$ & 0.704 & - & - & 0.70 & \\
\hline$S N 1<---S N$ & 0.820 & 0.079 & 18.217 & 0.82 & $* * *$ \\
\hline$S N 2<---S N$ & 0.779 & 0.075 & 18.227 & 0.78 & $* * *$ \\
\hline$S N 3<---S N$ & 0.624 & - & $\longrightarrow$ & 0.62 & \\
\hline
\end{tabular}




$\begin{array}{cccccc}S N 4<---S N & 0.445 & 0.072 & 11.868 & 0.45 & * * * \\ B I 1<---B I & 0.290 & 0.080 & 7.693 & 0.29 & * * * \\ B I 2<---B I & 0.280 & 0.079 & 7.905 & 0.28 & * * * \\ B I 3<---B I & 0.395 & - & - & 0.40 & \end{array}$

1 Notes: *** $p<0.01$.

2 4.5. Interaction effects among latent variables

3 Table 6 indicates that most interaction effects among latent variables are in line with

4 expectation. The paired interactions between $B A$ and $P B C(0.26, \mathrm{p}<0.01)$, between $B A$ and $S N$

$5 \quad(0.24, \mathrm{p}<0.01)$, between $B G$ and $P B C(0.30, \mathrm{p}<0.01)$, between $B G$ and $S N(0.13, \mathrm{p}<0.01)$, and

6 between $B A$ and $B G(0.62, \mathrm{p}<0.01)$ had significance levels less than 0.01 , partly supporting

7 hypothesis $H 5$. In addition, we found that the interaction between $B G$ and $B A(0.62)$ is the

8 greatest among all. In contrast, the mutual interactions between the other pairs of latent

9 variables were smaller. Those farmers with high $B G$ while also had positive attitudes towards

10 compliance behaviour and a higher $P B C$ were more likely to comply with pesticide

11 application standards. Next, a farmer with positive attitudes towards compliance behaviour

12 increased his/her intention to comply even further if he/she also received pressures from

13 his/her significant others. Also, the farmers who showed positive attitudes towards

14 compliance behaviour were more willing to comply if the compliance was also supported by

15 their $S N$. Finally, a farmer were even more willing to comply if he/she had a $S N$ that favoured

16 a proper use of pesticide requires conditional on that the farmer also had the ability to master

17 pesticide application.

\subsection{Factor loading of the measurement models}

19 Factor loadings manifest the impacts of observed variables on latent variables. The most 20 influential factor for $P B C$ was $P B C 3$ (0.90), i.e. the availability of technical assistance. This 21 implied that farmers were more likely to have higher $P B C$ if they were provided with 22 technical assistance. When it comes to the measurement of $B G$, product price was the most 23 influential factor with a standardised coefficient of 0.78 . The result indicated that farmers 24 were more likely to comply with pesticide usage standards if they have put more weight on 25 the selling prices of their products. For $B A$, the factor loading of $B A 3$ was the highest $(0.73)$ 26 among all indicators. The rationale was that they were more likely to comply if they have 
1 perceived that their compliance was beneficial to them. Finally, the most influential indicator

2 for $S N$ was the influence from family members (factor loading 0.82 ). This implied that

3 farmers' family members had the largest influences on their intentions to comply with

4 pesticide application standards.

\section{5. Conclusions and policy recommendations}

6 This study aimed at examining the major factors determining farmers' intentions to

7 comply with pesticide application standards under an extended framework of TPB estimated

8 by means of structural equation modelling. We considered psychological factors including

9 attitudes, subjective norms, perceived behavioural control and behavioural goal. Overall, the

10 results supported previous findings that it is important to consider psychological factors to

11 fully understand farmers' decisions (Lynne and Rola, 1988).

12 The traditional $T P B$ variables had significant correlations with the intentions of farmers

13 to comply with pesticide application standards, confirming the applicability of TPB in

14 analysing farmers' decision making in a developing country context. The results also

15 demonstrated the role of an additional factor integrated into the $T P B$, i.e. behavioural goal,

16 which provides further insights into farmers' pesticide usage behaviour. Farmers' intention

17 was influenced by significant others' opinions, behavioural goal, and perceived behavioural

18 control. An interesting finding is that farmers' $P B C$ was found to be the most influential

19 factor to determine farmers' intentions to comply with pesticide application standards. This

20 is in line with another study that examined Florida strawberry farmers' willingness to adopt

21 and to invest in water technology. In contrast, Wauters et al. (2010) found that $P B C$ was not

22 a significant factor in affecting farmers' decisions to adopt soil conservation practices. One

23 possible explanation could be that pests caused extensive damages to agricultural production,

24 which caused farmers to be more risk-averse. Next, the TPB analysis revealed that the lack

25 of qualified technical assistance was a significant obstacle constraining farmers' intentions

26 to comply pesticide application standards. This highlights a significant strength of the TPB

27 analysis that identifies which psychological factors are the main barriers. This research

28 suggests that interventions are necessary to foster farmers' behavioural control. Technical 
1 guidance is a useful tool to enhance farmers' control over pesticide application and to

2 promote the usage of pesticides in line with recommended standards.

This study also showed that $S N$ only had a marginal effect in explaining farmers' intention which was consistent with the findings reported in Xu et al. (2016) who looked at farmers' adoption decisions towards genetically modified rice. One possible explanation could be that individuals are unwilling to openly admit how others influenced their own attitudes, practices, and behaviours. Another possible explanation could be that complying with pesticide application standards is not supported by social norm. Nevertheless, the results showed that $S N$ interacted with $B A$ in influencing farmers' behaviour, indicating that social norm works better when it is coupled with a better attitude towards compliance. In addition, further analysis revealed that the pressure from farmers' family members had a the most influence in shaping their $S N$.

The importance of $B G$ in affecting farmers' compliance was supported in our study, consistent with the findings from Bergevoet et al. (2004) and Willock et al. (1999). This finding is also in line with previous suggestions that the relationship of $B G$ with intention varied across attitudes (Perugini and Conner, 2000). Furthermore, we revealed that product prices had the strongest effect on $B G$. The results demonstrated that farmers would focus on the additional value generated from agricultural products with higher quality and safety standards. This shows that with a rapid development in China's rural market economy Chinese farmers are not merely farm crop producers but also market suppliers who put heavy weight on product prices.

$B A$ also significantly correlated with farmers' intention to comply. Garforth et al. (2004) stated that farmers' attitudes towards technology strongly influenced their intentions to adopt. Similarly, Martínez-García et al. (2013) discovered that there was a positive correlation between attitudes towards and the intention to use improved grassland among small farmers in Mexico. Furthermore, Bruijnis et al. (2013) also found a positive correlation between the attitudes of Dutch farmers and their intentions to adopt the innovation to improve the health of dairy cows. Our results echoed with the above studies. Additionally, our results also suggested that a favourable attitude towards compliance was mostly influenced by farmers' perceived benefits. 
1 In addition to the expected major effects, four significant interaction effects were

2 observed. These interaction effects indicated that $P B C, B A, S N$, and $B G$ had indirect effects

3 on intention by facilitating the other latent variables. However, additional evidence for these

4 interactive effects should be explored further.

5 This study provides several insights for policy makers. Firstly, the fact that $P B C$ had the

6 greatest influence on farmers' intention to comply with pesticide application standards

7 implied that farmers' compliance may be hampered by farmers' limited abilities. Government

8 agencies should help farmers to overcome these obstacles by providing farmers with technical

9 guidance and designing long-term collaborative programmes that support, develop, and foster

10 sense of control among farmers. Secondly, this study showed that attitudes were significant

11 predictors of compliance behaviour. It is essential to provide farmers with training to change

12 their attitudes towards compliance. Thirdly, this study supported the role of subjective norms.

13 In order to increase farmers' intentions to use pesticides properly, government agencies should

14 increase social pressures on farmers. This can be done by promoting proper use of pesticides

15 not only to farmers, but also to their families and communities. Greater public awareness on

16 proper pesticide usage is expected to impose greater social pressures for farmers to comply.

17 Lastly, this study revealed that behavioural goal also played a role in promoting farmers'

18 intentions to comply with pesticide application standards. Therefore, a market mechanism

19 should be established such that safe agricultural products are sold at higher prices. A

20 limitation of the present study is that it has focused on farmers' intentions rather than their

21 actual pesticide spray actions. This should be investigated by future research. 
1

2

3

4

5

6

7

8

9

\section{$1 \quad$ Notes}

2 1. Farmer's intentions may be affected by crop type as well as other factors including competing farmers, farming characteristics including age, education level, farm size etc. However, due to the diversity of crops that have been cultivated by the farmers, it is infeasible to conduct sub-group analysis according to crop type. Farmer and farm characteristics were also not included in the conceptual model.

2. Both causal relations and correlations can be estimated by SEM. The two concepts look similar but are inherently different. Take the theoretical model in Figure 1 as an example. The solid lines represent casual relationships. The arrow from BA to BI indicates the casual impact from BA on BI. In contrast, the doted lines (with double-headed arrows) represent correlation relationships. PBC correlates with BA. We have made clear distinctions to "casual relationships" and "correlations" in the results.

3. Petroni and Braglia (2000): Bartlett's Test of Sphericity is based on the correlation matrix. Its null hypothesis is that the correlation matrix is an identity matrix.

\section{Reference}

Abhilash, P. C. and Singh, N. (2009), "Pesticide use and application: an Indian scenario", Journal of Hazardous Materials, Vol.165, No. 1, pp.1-12.

Acock, A. C. and DeFleur, M. L. (1972), “A configurational approach to contingent contingency in the attitude-behaviour relationship", American Sociological Review, Vol.37, No. 6, pp.714-726.

Ajzen I. and Fishbein M. (1980), Understanding attitudes and predicting social behaviour, Prentice Hall.

Ajzen, I. (1985), "From intentions to actions: A theory of planned behaviour", In:Kuhl, J. and Beckmann, J. (Ed.) Action-control: From cognition to behaviour, Springer Science \& Business Media, pp.11-39.

Ajzen, I. (1991), "The Theory of Planned Behaviour”. Organizational Behaviour and Human Decision Processes, Vol.50 No. 2, pp. 179-211.

Ajzen, I. and Driver, B. L. (1992), "Contingent value measurement: on the nature and meaning of willingness to pay”, Journal of Consumer Psychology, Vol. 1 No. 4, pp.297-316.

Ajzen, I. and Madden, T. J. (1986), "Prediction of goal-directed behaviour-attitudes, intentions, and 
perceived behavioural-control”, Journal of Experimental Social Psychology, Vol.22 No. 5, pp.453-474.

Bagozzi, R. P., Yi, Y. and Phillips, L. W. (1991), “Assessing construct validity in organizational research”, Administrative Science Quarterly, Vol.36 No. 3, pp.421-458.

Bai, L., Tang, J., Yang, Y. and Gong, S. (2014), "Hygienic food handling intention. An application of the theory of planned behaviour in the Chinese cultural context", Food Control, Vol.42 No.3, pp.172-180.

Beedell, J. and Rehman, T. (2000), “Using social-psychology models to understand farmers' conservation behaviour", Journal of Rural Studies, Vol. 16 No. 1, pp.117-127.

Beran, T. N. and Violato, C. (2010), “Structural equation modeling in medical research: a primer”. BMC Research Notes, No.3, pp. 267-277.

Bergevoet, R. H., Ondersteijn, C. J. M., Saatkamp, H. W., Van Woerkum, C. M. J.and Huirne, R. B. M. (2004), "Entrepreneurial behaviour of Dutch dairy farmers under a milk quota system: goals, objectives and attitudes", Agricultural Systems, Vol.80 No.1, pp.1-21.

Binswanger, H. P. (1980), “Attitudes towards risk: Experimental measurements in rural India”, American Journal of Agricultural Economics, Vol.62 No.3, pp.395-407.

Borges, J. A. R. and Lansink, A. G. O. (2016), "Identifying psychological factors that determine cattle farmers' intention to use improved natural grassland", Journal of Environmental Psychology, Vol.45, pp.89-96.

Borges, J. A. R., Lansink, A. G. O., Ribeiro, C. M. and Lutke, V. (2014), “Understanding farmers' intention to adopt improved natural grassland using the theory of planned behaviour", Livestock Science, Vol.169, pp.163-174.

Bourn, D. and Prescott, J. (2002), “A comparison of the nutritional value, sensory qualities, and food safety of organically and conventionally produced foods", Critical Reviews in Food Science and Nutrition, Vol.42 No. 1, pp. 1-34.

Browne, M. W. and Cudeck, R. (1993), “Alternative Ways of Assessing Equation Model Fit”, In: Bollen KA and Long JS (ed.) Testing structural equation models, Newbury Park: Sage, pp. 136-162.

Bruijnis, M. R.N., Hogeveen, H. and Stassen, E. N. (2013), "Measures to improve dairy cow foot health: consequences for farmer income and dairy cow welfare", Animal, Vol.7 No.1, pp. 167-175.

Burnkrant, R. E. and Cousineau, A. (1975), "Informational and Normative Social Influence in Buyer Behaviour", Journal of Consumer Research, Vol. 2 No. 3, pp.206-215. 
1

2

3

4

5

6

7

8

9

1 Carmines, E. G. and Mciver, J. P. (1981), Analyzing models with unobserved variables: analysis of covariance structures. In: Bohrnstedt, G.W. and Borgatta, E.F. (Eds.) Social Measurement: Current Issues. Sage, Beverly Hills, CA, pp. 65-115.

Chow, S. and Mullan, B. (2010), "Predicting food hygiene. An investigation of social factors and past behaviour in an extended model of the Health Action Process Approach”, Appetite, Vol.54 No.1, pp.126-133.

Damalas, C. A., Georgiou, E. B. and Theodorou, M. G. (2006), "Pesticide use and safety practices among Greek tobacco farmers: a survey”, International Journal of Environmental Health Research, Vol.16 No. 5, pp.339-348.

Damalas, C.A. and Hashemi, S.M. (2010), "Pesticide risk perception and use of personal protective equipment among young and old cotton growers in northern Greece”. Agrociencia, Vol. 44 No.3, pp.363-371.

Davis, L. E., Ajzen, I., Saunders, J. and Williams, T. (2002), "The decision of African American students to complete high school: An application of the theory of planned behaviour", Journal of Educational Psychology, Vol.94 No. 4, pp.810-819.

De Krom, M. P. and Mol, A. P. (2010), "Food risks and consumer trust. Avian influenza and the knowing and non-knowing on UK shopping floors", Appetite, Vol. 55 No. 3, pp.671-678.

Du B., Kang, J.P. and Li, S. B. (2014), “Analysis of Factors Affecting Farmers' Will to Produce Safely Based on TBP”, Journal of Northwest A \& F University (Natural Science Edition), Vol.14 No. 3, pp.71-75 (in Chinese).

Eagly, A. H. and Chaiken, S. (1993), The psychology of attitudes, Harcourt Brace Jovanovich College Publishers.

Escalada, M. and Heong, K. L. (2012), "Using Decision Theory and Sociological Tools to Facilitate Adoption of Biodiversity-Based Pest Management Strategies”, In: Gurr, G. M., Wratten, S. D. and Snyder, W. E. (Ed.) Biodiversity and Insect Pests: Key Issues for Sustainable Management, John Wiley and Sons, pp.197-213.

Fabrigar, L. R., Wegener, D. T., MacCallum, R. C. and Strahan, E.J. (1999), "Evaluating the use of exploratory factor analysis in psychological research", Psychological Methods, Vol.4 No. 3, pp.272-299.

Fielding, K.S., Terry, D.J., Masser, B. and Hogg, M.A. (2008), "Integrating social identity theory and the 
1 theory of planned behaviour to explain decisions to engage in sustainable agricultural practices", British Journal of Social Psychology, Vol. 47 No.1, pp.23-48.

Fishbein, M. and Ajzen, I. (1975), "Belief, attitude, intention and behaviour: An introduction to theory and research", Philosophy \& Rhetoric, Vol. 41 No. 4, pp.842-844.

5 Fishbein, M. and Ajzen, I. (2010), Predicting and Changing Behaviour: The Reasoned Action Approach, Psychology Press, New York.

Garforth, C., Rehman, T., Mckemey, K., Tranter, R., Cooke, R. and Yates, C., et al. (2004), "Improving the design of knowledge transfer strategies by understanding farmer attitudes and behaviour", Journal of Farm Management, Vol.12 No. 1, pp.17-32.

Gartrell, C. D. and Gartrell, J. W. (1985), "Social status and agricultural innovation: a meta-analysis", Rural Sociology, Vol.50 No. 1, pp.38-50.

Gao M., Xu T.X. and Ouyang T.Z. (2013), "The logic of peasant household behaviour and its policy implications", Thinking, No. 01, pp. 147-148(in Chinese).

Gasson, R. (1973), “Goals and values of farmers”, Journal of Agricultural Economics, Vol.24 No. 3 , pp.521-542.

Grieshop, J. I., Zalom, F. G.and Miyao, G. (1988), “Adoption and diffusion of integrated pest management innovations in agriculture", Bulletin of the Entomological Society of America, Vol. 34 No. 2, pp.72-79.

Grube, J. W., Morgan, M. and McGree, S. T. (1986), “Attitudes and normative beliefs as predictors of smoking intentions and behaviours: A test of three models", British Journal of Social Psychology, Vol.25 No. 2, pp.81-93.

Han Y. (1995), “A study on Chinese farmers' production behaviour”, Economy Perspectives, No.5, pp.29-33 (in Chinese).

Hansson, H., Ferguson, R. and Olofsson, C. (2012), "Psychological constructs underlying farmers' decisions to diversify or specialise their businesses-An application of theory of planned behaviour", Journal of Agricultural Economics, Vol.63 No. 2, pp. 465-482.

Homans, G. C. (1961), Social behaviour and its elementary forms, Routledge \& Paul, London.

Hruska, A. J. and Corriols, M. (2002), "The impact of training in integrated pest management among Nicaraguan maize farmers: increased net returns and reduced health risk", International Journal of Occupational and Environmental Health, Vol.8 No. 3, pp. 191-200.

Jallow, M. F., Awadh, D. G., Albaho, M. S., Devi, V. Y. and Thomas, B. M. (2017), "Pesticide risk 
1

2

3

4

5

6

7

8

9

1 behaviours and factors influencing pesticide use among farmers in Kuwait", Science of the Total 2 Environment, No. 574, pp. 490-498.

3 Jiang, J.Y., Ke, M.F., Zhang, S.Y. and Yin, C.B. (2012), “An Analysis of Factors Affecting Farmers'

Willingness to Vegetable Quality and Safety Control-Based on the Survey of 151 Farmers in Gaocheng, Hebei Province", Journal of Agrotechnical Economics, No.5, pp.35-42 (in Chinese).

Kline, R. B. (2015), Principles and practice of structural equation modeling. New York, NY: Guilford. publications.

Krueger, N. F., Reilly, M. D. and Carsrud, A. L. (2000), "Competing models of entrepreneurial intentions", Journal of Business Venturing, Vol.15 No.5, pp.411-432.

Karppinen, H. (2005), "Forest owners' choice of reforestation method: an application of the theory of planned behaviour", Forest Policy and Economics, Vol.7 No.3, pp.393-409.

Khan, M., Mahmood, H. Z. and Damalas, C. A. (2015), "Pesticide use and risk perceptions among farmers in the cotton belt of Punjab, Pakistan", Crop Protection, No.67, pp. 184-190.

Kong, X.Z. (1998), "Study on the goal of economic behaviour of farmers in China", Journal of Agrotechnical Economics, No. 2, pp.24-27 (in Chinese).

Läpple, D. and Kelley, H. (2013), "Understanding the uptake of organic farming: accounting for heterogeneities among Irish farmers", Ecological Economics, Vol. 88 No. 7, pp. 11-19.

Leone, L., Perugini, M. and Ercolani, A. P. (1999), “A comparison of three models of attitude-behaviour relationships in the studying behaviour domain”, European Journal of Social Psychology, Vol.29 No.23, pp.161-189.Lin, Y.F. (1988), "Farmer and economic rationality”, China Rural Survey, No. 3, pp.31-33 (in Chinese).

Liu, E. M. and Huang, J. (2013), "Risk preferences and pesticide use by cotton farmers in China", Journal of Development Economics, No.103, pp.202-215.

Locke, E. A. and Bryan, J. F. (1969), “The directing function of goals in task performance”, Organizational Behaviour and Human Performance, Vol.4 No.1, pp. 35-42.

Locke, E. A. and Latham, G. P. (2006), "New directions in goal-setting theory", Current directions in psychological science, Vol.15 No. 5, pp.265-268.

Lynne, G. D., Casey, C. F., Hodges, A. and Rahmani, M. (1995), “Conservation technology adoption decisions and the theory of planned behaviour", Journal of Economic Psychology, Vol.16 No. 4, pp. $581-598$. 
1 Lynne, G. D. and Rola, L. R. (1988), “Improving Attitude-behaviour prediction models with economic 2 variables: farmer actions toward soil conservation", Journal of Social Psychology, Vol.128 No. 1, pp.

3

4 5

6 7 19-28.

Marcoux, C. and Urpelainen, J. (2011), "Special interests, regulatory quality, and the pesticides overload", Review of Policy Research, Vol. 28 No. 6, pp.585-612.

Martínez-García, C. G., Dorward, P. and Rehman, T. (2013), "Factors influencing adoption of improved grassland management by small-scale dairy farmers in central Mexico and the implications for future research on smallholder adoption in developing countries", Livestock Science, Vol.152 No.2, pp. 228-238.

Matthews, G., (2008), “Attitudes and behaviours regarding use of crop protection products - a survey of more than 8500 smallholders in 26 countries", Crop Protection, No. 27, pp.834-846.

Mazzocchi, M., Lobb, A. E. and Traill, W. B. (2006), Food Scares and Consumer Behaviour: A European Perspective. In 2006 Annual Meeting, August 12-18, 2006, Queensland, Australia (No. 25613). International Association of Agricultural Economists.

McGilligan, C., McClenahan, C. and Adamson, G. (2009), “Attitudes and intentions to performing testicular self-examination. Utilizing an extended theory of planned behaviour", Journal of Adolescent Health, Vol.44 No.4, pp.404-406.

McGuire, W. J. (1969), "The nature of attitudes and attitude change”, The handbook of social psychology, Vol.3 No. 2, pp.136-314.

Ngowi, A. V. F., Mbise, T. J., Ijani, A. S. M., London, L., and Ajayi, O. C. (2007), "Smallholder vegetable farmers in Northern Tanzania: Pesticides use practices, perceptions, cost and health effects", Crop Protection, Vol.26 No. 11, pp.1617-1624.

Pampel, F. and van Es, J. C. (1977), "Environmental quality and issues of adoption research", Rural Sociology, Vol.42 No. 1, 57-71.

Perugini, M. and Conner, M. (2000), "Predicting and understanding behavioural volitions: The interplay between goals and behaviours", European Journal of Social Psychology, Vol.30 No. 5, pp.705-731.

Xu, R.M., Wu, Y.R. and Luan, J.D., (2016), “Analysis of farmers’ willingness to adopt genetically modified insect-resistant rice in China”, China Agricultural Economic Review, Vol. 8 No. 3, pp.368-382.

Smith, J. R., Terry, D. J., Manstead, A. S., Louis, W. R., Kotterman, D. and Wolfs, J. (2007), “Interaction effects in the theory of planned behaviour: the interplay of self-identity and past behaviour", Journal 
1

2

3

4

5

6

7

8

9

$1 \quad$ of Applied Social Psychology, Vol. 37 No. 11, pp.2726-2750.

2 Stadlinger, N., Mmochi, A. J., Dobo, S., Gyllbäck, E., and Kumblad, L. (2011), "Pesticide use among smallholder rice farmers in Tanzania”, Environment, Development and Sustainability, Vol. 13 No.3, pp.641-656.

5 Van Asselt, E. D., Meuwissen, M. P. M., Van Asseldonk, M. A. P. M., Teeuw, J. and Van der Fels-Klerx, H. J. (2010), "Selection of critical factors for identifying emerging food safety risks in dynamic food production chains", Food Control, Vol. 21 No.6, pp.919-926.

Vanslembrouck, I., Huylenbroeck, G. V. and Verbeke, W. (2002), "Determinants of the willingness of Belgian farmers to participate in agri-environmental measures", Journal of Agricultural Economics, Vol. 53 No. 3, pp.489-511.

Verbeke, W. and Vackier, I. (2005), "Individual determinants of fish consumption: application of the theory of planned behaviour", Appetite, Vol.44 No.1, pp.67-82.

Wang, H.T. and Wang, K. (2012), “An Analysis of Factors Affecting Pig Farmers' Production Safety Decision-making Behaviour-An Empirical Research by Groups Structural Equation Modeling”, Chinese Rural Economy, No.11, pp.21-30 (in Chinese).

Wauters, E., Bielders, C., Poesen, J., Govers, G. and Mathijs, E. (2010), “Adoption of soil conservation practices in Belgium: an examination of the theory of planned behaviour in the agri-environmental domain", Land Use Policy, Vol.27 No. 1, pp.86-94.

Willock, J., Deary, I. J., Mcgregor, M. M., Sutherland, A., Edwards-Jones, G. and Morgan, O., et al. (1999), "Farmers' attitudes, objectives, behaviours, and personality traits: the Edinburgh study of decision making on farms", Journal of Vocational Behaviour, Vol.54 No.1, pp. 5-36.

Wilson, G. A. (1996), "Farmer environmental attitudes and ESA participation", Geoforum, Vol.27 No.2, pp.115-131.

Wright, S. (1920),"The relative importance of heredity and environment in determining the piebald pattern of guinea-pigs", Proceedings of the National Academy of Sciences of the United States of America, Vol.6 No.6, pp.320-332.

Wu, L.H. and Hou, B. (2012), "China's farmer perception of pesticide residues and the impact factors: The case of Jiangsu Province", China Agricultural Economic Review, Vol. 4 No.1, pp.84-104.

Yang, X.B. (2003), "Pesticide pollution and food safety control”, Journal of Preventive Medicine Information, Vol.19 No.1, pp.21-23 (in Chinese). 
1 Zhao, J.X. and Zhang, Z.G. (2009), “An Empirical Analysis of Farmers’ Decision-making Mechanism of 2 Supplying Safe Vegetable - Based on the Survey of Vegetable Farmers in Dingzhou, Hebei Province,

3 Shouguang, Shandong Province and Linhai, Zhejiang Province", Journal of Agrotechnical Economics,

$4 \quad$ No.5, pp. 31-38 (in Chinese).

5 Zhou, J. H. (2006), “Analysis of Factors Affecting Farmers' Vegetables Quality and Safety Control

6 Behaviour”, Chinese Rural Economy, No. 11, pp. 25-34 (in Chinese).

7 Zimmerer, T., Scarborough, N. M. and Wilson, D. (2005), Essentials of entrepreneurship and small

8 business management, Pearson/Prentice Hall. 